University of Nebraska - Lincoln

DigitalCommons@University of Nebraska - Lincoln

Faculty Publications from the Department of Electrical \& Computer Engineering, Department Electrical and Computer Engineering

2007

\title{
Work in Progress - Increasing Transfer Student Enrollment, Retention and Graduation through the Strengthening Transitions into Engineering Programs
}

\author{
Stephanie G. Adams \\ University of Nebraska-Lincoln \\ Lance C. Pérez \\ University of Nebraska-Lincoln, Iperez@unl.edu \\ John J. Ballard \\ University of Nebraska-Lincoln
}

Follow this and additional works at: https://digitalcommons.unl.edu/electricalengineeringfacpub

Part of the Electrical and Computer Engineering Commons

Adams, Stephanie G.; Pérez, Lance C.; and Ballard, John J., "Work in Progress - Increasing Transfer Student Enrollment, Retention and Graduation through the Strengthening Transitions into Engineering Programs" (2007). Faculty Publications from the Department of Electrical and Computer Engineering. 155.

https://digitalcommons.unl.edu/electricalengineeringfacpub/155

This Article is brought to you for free and open access by the Electrical \& Computer Engineering, Department of at DigitalCommons@University of Nebraska - Lincoln. It has been accepted for inclusion in Faculty Publications from the Department of Electrical and Computer Engineering by an authorized administrator of DigitalCommons@University of Nebraska - Lincoln. 


\title{
Work in Progress - Increasing Transfer Student Enrollment, Retention and Graduation through the Strengthening Transitions into Engineering Programs
}

\author{
Stephanie G. Adams ${ }^{1}$, Lance C. Pérez ${ }^{2}$, John J. Ballard ${ }^{3}$
}

\begin{abstract}
Large populations of students are matriculating to community colleges $(\mathrm{CC})$. However, transferring from a $\mathrm{CC}$ to 4-year undergraduate engineering degree program is often quite difficult. There are few, if any, engineering courses offered at the CCs. In addition, long prerequisite chains reduce many transfer students to Freshman or Sophomore status, even though they have had two years of post-secondary education. The University of Nebraska-Lincoln (UNL), Strengthening Transitions into Engineering Programs (STEP) is a program designed to facilitate the transfer of $\mathrm{CC}$ students to undergraduate baccalaureate engineering degree programs. The program consists of four engineering courses taught at the CCs with support from UNL and several complementary student support programs. This paper discusses the specific courses and strategies being implemented and the progress to date of the UNL STEP program.
\end{abstract}

Index Terms - Transfer students, Transfer Pathways, Community College

\section{INTRODUCTION}

There is a nationwide need for engineering talent, especially from minority and female populations [1],[2]. Across the nation, high school graduates are increasingly beginning postsecondary education at community colleges (CCs) and then transferring to 4-year institutions. According to the Higher Education Task Force 2004 Baseline Report: Challenges and Opportunities for Nebraska [3], there is an increase in the number of students going to CCs in the State of Nebraska. Transferring from a CC to a 4-year undergraduate degree program is always challenging, but is especially difficult for potential engineering students due to the lack of engineering courses offered at the CCs and the long prerequisite chains frequently found in engineering curricula.

While articulation agreements exist between the CCs and some UNL disciplines, no agreement is in place with the College of Engineering (COE). The implication is that students who transfer to the COE lose their junior standing even though they have completed two years of study. These students would then often take nearly double the engineering and science course load of students who began their education at the 4-year granting institution trying to "catch up". As a result, student's GPA and overall feelings of success suffers. To address this issue, COE faculty and the Chief Instructional Officers of the CCs propose to develop four introductory engineering courses that can be offered at the CCs and that will transfer to UNL as engineering courses in most undergraduate engineering curricula. This effort is being funded by a 5-year National Science Foundation (NSF), Division of Undergraduate Education, Strengthening Transitions in Engineering Programs (STEP) grant. UNL is currently in the first year of this grant.

\section{Proposed Solution}

The University of Nebraska-Lincoln (UNL), in partnership with Nebraska's six community colleges, has designed a preprogram which was recently funded by the National Science Foundation to institutionalize an effective program that enables students to complete select freshman and sophomore engineering courses at the $\mathrm{CCs}$ and transfer seamlessly into the UNL College of Engineering (CoE). The UNL STEP Program has three components: 1) developing and implementing four introductory engineering courses that will be taught at the CCs; 2) establishing a complementary set of student supports that facilitate mentoring, community building, and retention, particularly among women and minorities; and 3) facilitating paid internship opportunities to complement the high quality instruction students will receive in the CoE.

\section{I) Introductory Engineering Courses}

The courses will be developed by teams consisting of the PIs, UNL faculty from appropriate disciplines, and CC faculty that will be teaching the respective course. ENGR 101 and ENGR 201 will be offered beginning the Fall 2007 semester. The remaining courses will begin in the Spring of 2008 with all course offerings in a steady state by the Fall of 2008.

\section{II) Student Support}

The following will serve as the foundation for student academic and social support to ensure students success.

\footnotetext{
${ }^{1}$ Stephanie G. Adams, Associate Dean of Undergraduate Studies, College of Engineering, University of Nebraska-Lincoln, Lincoln, NE sadams@unl.edu

${ }^{2}$ Lance C. Pérez, Associate Dean of Academic Affairs, College of Engineering, University of Nebraska-Lincoln, Lincoln, NE, lperez@unl.edu

${ }^{3}$ John J. Ballard, Associate Dean, College of Engineering, University of Nebraska-Lincoln, Lincoln, NE, jballard@unl.edu 


\begin{tabular}{|l||l|l|}
\hline Class & Hr & Purpose \\
\hline ENGR 101 & $\begin{array}{l}3 \mathrm{chrs} / \\
4.5 \\
q \mathrm{hrs}\end{array}$ & $\begin{array}{l}\text { Freshman Multidisciplinary Design: Introduce } \\
\text { freshman students to the engineering problem solving } \\
\text { process in the context of several disciplines and develop } \\
\text { teamwork and communication skills. }\end{array}$ \\
\hline ENGR 102 & $\begin{array}{l}3 \mathrm{chrs} / \\
4.5 \\
\text { qhrs }\end{array}$ & $\begin{array}{l}\text { MATLAB Programming and Problem Solving: } \\
\text { Computer programming course that teaches structured } \\
\text { programming and problem solving using computers. } \\
\text { Consists of a sequence of programming assignments that } \\
\text { require students to write MATLAB programs to solve } \\
\text { engineering problems. }\end{array}$ \\
\hline ENGR 201 & $\begin{array}{l}3 \mathrm{chrs} / \\
4.5 \\
\text { qhrs }\end{array}$ & $\begin{array}{l}\text { Introduction to Circuits and Electronics: Basic } \\
\text { analysis of passive and electronic circuits. }\end{array}$ \\
\hline ENGR 202 & $\begin{array}{l}3 \mathrm{chrs} / \\
4.5\end{array}$ & $\begin{array}{l}\text { Engineering Statics: Basic engineering statics that will } \\
\text { be based on the existing UNL course. }\end{array}$ \\
\hline qhrs
\end{tabular}

TABLE 1: COURSE DESCRIPTION S FOR STEP CURRICULUM

Campus Visits. Students from CCs will attend transfer workshops on the UNL campus. During the workshop students will also attend information sessions, hands-on demonstrations, and presentations by faculty and/or current students, tour the college and the university, and make classroom visits.

Summer Transfer Enrichment Program. Many transfer students are understandably nervous about moving from a small college to a large university. The summer after a student's sophomore year, they are invited to a free multi-day campus visit to learn about campus resources and meet the people who will make UNL feel like home. This provides students the opportunity to network with future classmates and talk to faculty about what courses to take.

Parent Orientation Program. Parents get their questions answered during a one-day seminar that covers topics such as academic majors and degree requirements, typical engineering students' experiences, the College of Engineering's expectations, nonacademic support services, and adjustments transfer students may face. Parents develop their own network with other parents.

Peer Mentoring Program. Current engineering students will help transfer students adapt to university life during their first year at UNL. Peer mentors counsel others in coping with study demands, understanding the university's expectations, and developing and improving study strategies.

\section{III) Internships}

Students will be required to complete a 10- to 12-week summer internship in their field of study. Internships help students gain work experience and connect concepts learned in the classroom to real-world experiences. The internships will take place during the summer following the freshmen and sophomore year. An internship experience enhances classroom experiences by providing practical work experiences in areas related to course content and career goals. Internships will also serve as a way for students to gain valuable work experience, connect classroom experiences and concepts to real-world experiences, gain a better understanding of corporate America, and earn money for school expenses.

To facilitate these internships, UNL plans to work with organizations such as INROADS, the Nebraska Chapter of the National Society of Professional Engineers (NeSPE), and the American Council of Engineering Companies (ACEC) to identify internship opportunities for student participants.

\section{Program Goals}

The programs goals for this five year effort are:

1. An increase in the number of students transferring into engineering at UNL such that by the end of the project, the percentage of transfer students choosing engineering is equal to the COE's percentage of total students enrolled.

2. An increase of $100 \%$ of the number of underrepresented minority students transferring into the COE during each year of the grant period.

3. An increase of $100 \%$ of the number of women transferring into the COE during each year of the grant period.

4. A minimum retention rate of $80 \%$ for all transfer students.

5. A minimum graduation rate of $65 \%$ for of all transfer students after three years of enrollment in the COE.

The progress associated with this grant is being assessed and monitored by an Internal Advisory Board, External Advisory Board, Evaluation Team and the Chief Instructional Officers of the Community Colleges.

\section{CONCLUSIONS}

UNL is currently in the first year of a 5-year NSF STEP grant that supports a statewide effort to facilitate the transfer of community college students into undergraduate engineering degree programs. During the first year, the four courses are being developed in a partnership between UNL and the CCs and developing programmatic materials for use by support staff.

\section{REFERENCES}

[1]. The Engineer of 2020: Visions of Engineering in New Century, National Academy Press, 2004.

[2]. Rising Above the Gathering Storm: Energizing and Employing America for a Brighter Economic Future, National Academy Press, 2006.

[3]. LR174 Higher Education Task Force 2004 Baseline Report: Challenges and Opportunities for Nebraska http://www.ccpe.state.ne.us/PublicDoc/CCPE/Reports/LR174/ 2005/LR75sectopn4.pdf

October 10 - 13, 2007, Milwaukee, WI

\section{$37^{\text {th }}$ ASEE/IEEE Frontiers in Education Conference}

